\title{
CHARACTER ASSOCIATION AND PATH ANALYSIS IN GARLIC (Allium sativum L) FOR YIELD AND ITS ATTRIBUTES
}

\author{
S. R. Singh, N. A. Ahmed, S. Lal, Asima Amin ${ }^{1}$, Mudasir Amin \\ S. A. Ganie and Nusrat Jan \\ Central Institute of Temperate Horticulture, K.D. Farm, Old Air field \\ P.O. Rangreth, Srinagar (J\&K)-190007, India
}

\begin{abstract}
Character association and path analysis in twenty genotypically diverse indigenous genotypes of garlic (Allium sativum L.) were studied at the Central Institute of Temperate Horticulture, Srinagar during the years 2010 and 2011 for nine important characters. Total bulb yield showed positive and significant genotypic and phenotypic associations with plant height, number of leaves per plant, pseudo-stem length, bulb weight and number of cloves per bulb, indicating that selection based on these traits will help increasing the yield of garlic. Path coefficient analysis provides an effective means of a critical examination of specific force action to produce a given correlation and measure the relative importance of each factor. In this analysis bulb yield was taken as dependant variable and rest characters were considered as independent variable. Bulb weight showed high positive and direct effect and significant positive correlation with total bulb yield. Therefore, bulb with higher weight should be considered in selection criteria for increasing the total bulb yield and emphasis should be given for selecting the genotypes with higher bulb weight. Overall path analysis indicated that direct effect of bulb weight and equatorial bulb diameter and indirect effect of plant height, number of leaves per plant, pseudo stem length, polar bulb diameter, equatorial bulb diameter, number of cloves per bulb and average weight of 50 cloves should be considered simultaneously for amenability of total bulb yield.
\end{abstract}

Key words: Garlic, Allium sativum L. correlation, path analysis, yield.

\footnotetext{
${ }^{1}$ Corresponding author email: asimaamin@rediffmail.com
}

Received: 26.08.2012 
S. R. Singh et al.

\section{INTRODUCTION}

Garlic (Allium sativum L.) belongs to family Alliaceae is one of the most important crop of Allium group next to onion grown throughout the world over in 1.37 million hectare area with 22.282 million tons production and $16.26 \mathrm{t}$ ha ${ }^{1}$ productivity (FAOSTAT-2012). China is the world leader in production (80\%) followed by India (4.8\%). Though India is second in area and production but productivity is much low $\left(4.8 \mathrm{t} \mathrm{ha}^{-1}\right)$ as compared to China $\left(23.06 \mathrm{t} \mathrm{ha}^{-1}\right)$, Egypt (23.03 t ha ${ }^{-1}$ ), USA (18.94 $\left.\mathrm{t} \mathrm{ha}^{-1}\right)$ and Republic of Korea (12.67 tha $\left.{ }^{-1}\right)$. Major cause of low productivity is poor yield potential of varieties coupled with susceptibility to pest and diseases.

Scanty information on specific genetic behavior of garlic limited the options of crop improvement for the breeder. Clonal selection is a major breeding method for garlic since plant sterility usually precludes crop improvement through cross hybridization. Nevertheless, garlic shows wide morphological and agronomic variations in colour, size of bulb, plant height, flowering, number and size of the cloves, days to harvesting, resistance to storage capacity, dormancy and adaptation to agro-climatic situations (Mario et al., 2008). Despite the importance of crop very limited breeding work has been done so far. However, yield is a complex character and its direct improvement is difficult. A crop breeding programme aimed at increasing the plant productivity requires consideration not only on yield but also its components that have direct or indirect influences on yield. Knowledge in respect of nature and magnitude of association with different component characters is a prerequisite to bring the improvement in desired direction.

\section{MATERIALS AND METHODS}

The present research was carried out at the research farm of Central Institute of Temperate Horticulture, Srinagar, for two consecutive years i.e. 2010 to 2011. Geographic position of the experimental site lies between latitude of $34^{0} 5 \mathrm{~N}$ and longitude of $74^{0} 5 \mathrm{E}$ at an altitude of $1640 \mathrm{~m}$ above the sea level under temperate region. Soil of experimental field was sandy loam with slightly acidic pH (6.81). Twenty genotypes (BG 111, BG 110, BG 109, BG 108, BG 107, BG 106, CG 119, CG 118, CG 117, CG 116, CG 115, CG 114, CG 113, CG 112, AG 121, AG 120, AG 105, AG 101, AG 103 \& AG 102) were taken for the study. Garlic cloves transplanted in main field during rabi season during both the years. Each accession was planted in 10 row of two meter length with a spacing of $20 \times 10 \mathrm{~cm}$. The experiment was conducted under randomized block design replicated three times Recommended cultural and plant protection measures were followed to raise a healthy crop and good expression of the characters. Observations were recorded on randomly selected plants from each plot for nine characters namely, plant height $(\mathrm{cm})$, number of leaves per plant, polar diameter $(\mathrm{cm})$, equatorial diameter $(\mathrm{cm})$, average bulb weight $(\mathrm{g})$, average weight of 50 cloves (g), number of cloves per bulb, 
pseudo stem length ( $\mathrm{cm}$ ) and marketable yield ( $\mathrm{t}$ ha ${ }^{-1}$ ). Pooled data of two years were subjected to statistical analysis on agro-morphological quality traits using XL STAT-2011 and SAS 9.2 software SAS Institute (2011).

\section{RESULTS AND DISCUSSION}

The major causes underlying association are either due to pleiotropic gene action or linkage or both. The phenotypic correlation includes genotypic and environmental effects, which provides information between the observable characters. Phenotypic correlations provides information about the association between two characters, whereas genotypic correlation provides a measure of genetic association between the characters and normally used in selection, while as a genetic and environmental architecture of a genotype plays a great role in achieving the higher yield coupled with better quality. The genotypic and phenotypic correlation for bulb yield and its components in garlic are presented in table1. Findings clearly indicated that genotypic correlations were of higher magnitude than the corresponding phenotypic ones, thereby establishing strong inherent relationship among the characters studied. Low phenotypic value might be due to appreciable interaction of genotypes with environments. The present findings are in conformity with Tsega et al., 2010 and Dubey et al., 2010. Total bulb yield showed positive and significant genotypic and phenotypic associations with plant height, number of leaves per plant, pseudo-stem length, bulb weight and number of cloves per bulb, indicating that selection based on these traits will help in increasing the yield. This may be due to improvement in plant height, leaf number and stem length as they have physiological capacity to mobilize and translocate photosynthates to organ of economic value which in turn might have increased the bulb yield as observed in this study. Dubey et al., 2010 and Tsega et al., 2010 reported similar findings in garlic.

Correlation among yield and yield components and other quantitative traits helps in understanding the interdependence of the traits. Plant height showed a positive and significant relationship with number of leaves per plant, pseudo-stem length, number of cloves per bulb and average weight of 50 cloves that might have partially contributed to the total yield ( $\mathrm{t} \mathrm{ha}{ }^{-1 \text { tha }}$ ). Number of leaves per plant indicated positive and significant genotypic and phenotypic correlation with bulb weight, average weight of 50 cloves and total yield. This may be due to increase in photosynthate assimilates with increasing the leaf number which has increased the bulb weight, 50 cloves weight and total yield. Pseudo-stem length also showed a significant and positive phenotypic and genotypic correlation with bulb weight, number of cloves per bulb, average 50 clove weight and ultimately with total yield. Polar bulb diameter and equatorial bulb diameter showed a positive correlation with all the traits related to yield which could be the factor for selection to improve the yield. Bulb weight, have significant and positive genotypic and phenotypic correlation with number of cloves per bulb and average weight of 50 cloves and significant correlation with yield and these characters may be used as traits for 
selection to improve the yield of garlic. The findings are in conformity with the findings of Figliuolo et al., 2001 and Shri Dhar, 2002.

Path coefficient analysis is an important tool for partitioning the correlation coefficients into direct and indirect effects of independent variables on a dependant variable with the inclusion of more variables in correlation study when their indirect association becomes more complex. Two characters may show the correlation just because they are correlated with common third one. In such circumstances path coefficient analysis provides an effective means of a critical examination of specific force action to produce a given correlation and measure the relative importance of each factor. In this analysis bulb yield was taken as dependant variable and rest characters were considered as independent variable. The path coefficient analysis splits the total correlation coefficient of different traits into direct and indirect effect on total bulb yield in such a manner that the sum of direct and indirect effects is equal to total genotypic correlation.

The results shown in table 2, revealed that bulb weight showed the highest positive direct effect (23.780) on total bulb yield followed by equatorial bulb diameter (1.343) whereas plant height (-0.423), number of leaves/plant (-0.752), pseudo stem length (-0.145), polar bulb diameter (-4.895), number of cloves/bulb (1.956) and average 50 cloves weight (-18.806) showed direct negative effect on total bulb yield ( $\mathrm{t} \mathrm{ha}^{-1}$ ) whereas total sum of direct and indirect effects of plant height (0.778), number of leaves per plant (0.113), pseudo stem length (0.156), polar bulb diameter (0.893), equatorial bulb diameter (0.845) and average weight of 50 cloves (0.943) showed positive effect on total yield $\left(\mathrm{t} \mathrm{ha}^{-1}\right)$. Plant height showed positive indirect effect on total bulb yield via number of leaves per plant (0.059), pseudo stem length (0.035), polar bulb diameter (3.926), equatorial bulb diameter (0.999), bulb weight (18.309), number of cloves per bulb (0.652) and average weight of 50 cloves (13.443). Number of leaves per plant showed positive indirect effect on total bulb yield via plant height (0.033), pseudo stem length (0.018), polar bulb diameter (1.333), equatorial bulb diameter (0.149), bulb weight (4.760), number of cloves/bulb (0.871) and average weight of 50 cloves (1.824). Pseudo stem length exhibited positive indirect effect on total bulb yield through plant height (0.102), number of leaves per plant (0.994), polar bulb diameter (0.675), equatorial bulb diameter (0.121), bulb weight (4.194), number of cloves per bulb (0.203) and average weight of 50 cloves (3.128). Equatorial bulb diameter reflected positive indirect effect through plant height (0.315), number of leaves per plant (0.084), pseudo stem length (0.013), polar bulb diameter (4.312), bulb weight (20.256), number of cloves per bulb (0.409) and average 50 cloves weight (15.621). Bulb weight demonstrated indirect effect on total bulb yield through plant height (0.326), number of leaves per plant (0.151), pseudo stem length (0.026), polar bulb diameter (4.743), Equatorial bulb diameter (1.144), number of cloves per bulb (0.197) and average weight of 50 cloves (18.526). Number of cloves per bulb showed indirect effect on total bulb yield via plant height (0.141), number of leaves per plant (0.333), pseudo stem length (0.015), 
polar bulb diameter (1.332), equatorial bulb diameter (0.281), bulb weight (2.395) and average weight of 50 cloves (0.056). Average weight of 50 cloves reflected positive indirect effect on total bulb yield through equatorial bulb diameter (1.116), bulb weight (23.426) and number of cloves per bulb (0.121) whereas negative indirect effect via plant height $(-0.302)$, number of leaves per plant $(-0.073)$, pseudo stem length (-0.024) and polar bulb diameter (-4.513).

Path analysis revealed high direct contribution of bulb weight (23.780) and equatorial bulb diameter (1.434) on total bulb yield. Dubey et al., 2010 and Ghodhani and Singh (2000) also reported similar results in their findings. However, indirect positive contribution of plant height, number of leaves per plant, number of cloves per bulb were appreciable for the yield. The findings get support with findings of Singh et al., 2011.

The effect of residual factor (0.473) on total bulb yield was normal thereby suggest that some minor yield components are left out in programme. In present investigation bulb weight showed high positive and direct effect and had significant positive correlation with total bulb yield. Therefore, bulb with higher weight should be considered in selection criteria for increasing the total bulb yield and emphasis should be given for selecting the genotypes with higher bulb weight. Overall path analysis suggests that direct effect of bulb weight and equatorial bulb diameter whereas indirect effect of plant height, number of leaves/plant, pseudo stem length, polar bulb diameter, equatorial bulb diameter, number of cloves/bulb and average weight of 50 cloves should be considered simultaneously for amenability of total bulb yield.

The unexplained variation in genotypic path co-efficient was 0.473. It predicted that 0.527 percent variation at genotypic level has been determined and further indicated that some more factors not considered in this study contributed for total bulb yield. Therefore, some more traits need to be considered while selecting the genotypes for higher yield under temperate region.

\section{REFERENCES}

Dubey, B. K., Singh, R. K. and Bhonde, S. R . 2010 . Variability and selection parameters for yield and yield contributing traits in garlic (Allium sativum L.). Indian Journal of Agricultural Sciences, 80(8): 737-41.

Food and Agricultural commodities production. FAOSTAT | (C) FAO Statistics Division 2012| 23 August 2012 from http://faostat.fao.org/site/339/default.aspx

Fasika, S. 2004. Variability and association among bulb yield, yield components and quality parameters in Shallot (Allium cepa var. aggregatum). M. Sc thesis submitted to the school of Graduate studies of Alemaya University P - 83.

Figliuolo, G. candido, V. Logozzo, G and Zeuli, P.L. S.2001. Genetic evaluation of cultivated garlic germplasm . Euphytica, 121: 325-34. 
Godhani, P.V. and Singh, S. P. 2000. Genetic variability, correlation and path coefficient studies in Garlic (Allium Sativum L.). Approaches for sustainable development of onion and garlic Kirti Singh, Lawande K E, Pandey U B, Lallan Singh and Bhonde S R (Eds). Proceedings of the National Symposium on Onion and Garlic Production and Post Harvest Management Challenges and Strategies P 95-98.

Mario, P. C., Viviana, B. V. and Marya, I. A. 2008. Low genetic diversity among garlic accessions detected using RAPD. Chilean Journal of Agricultural Research, 68: 3-12.

Shri, Dhar. 2002. Genetic variability and character association in garlic. Progressive Horticulture, 34: 88-91.

Singh, R. K., Dubey, B. K. Bhonde. S. R., Gupta, R. P. 2011.Correlation and path coefficient analysis in garlic (Allium satium L).Journal of Spices and Aromatic crops, 20(2):81-85

SAS 2011. SAS Institute enterprise guide, Version 9.2. SAS Inst., Cary, NC, USA.

XLSTAT 2011. Specializes in Statistical \& Data Analysis Software for Excel 2011.http:www.

XLStat.com

Tsega, K., Tiwari, A. and Woldetsadik, 2010. Genetic variability, correlation and path coefficient among bulb yield and yield traits in Ethiopian garlic germplasm. Indian Journal of Horticulture, 67 (4): 489-99. 
Table 1: Estimation of correlation coefficient at the phenotypic and genotypic levels for various yield \& yield attributing traits

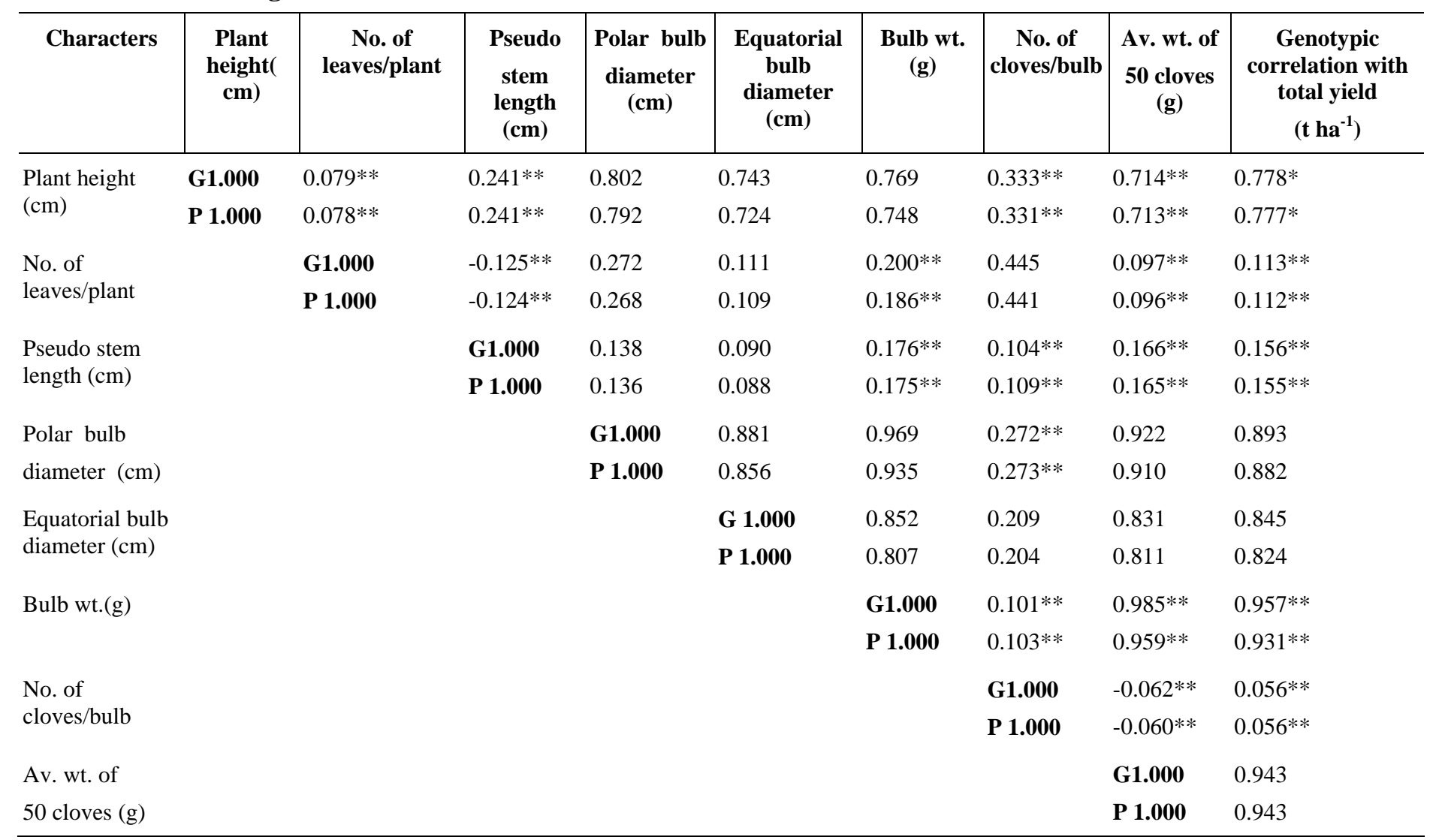

*. Correlation is significant at the 0.05 level

**.Correlation is significant at the 0.01 level 
Table-2: Direct (Bold) and Indirect effects of different yield and yield attributes in garlic

\begin{tabular}{|c|c|c|c|c|c|c|c|c|c|}
\hline Characters & $\begin{array}{c}\text { Plant } \\
\text { height } \\
(\mathbf{c m})\end{array}$ & $\begin{array}{c}\text { No. of } \\
\text { leaves/p } \\
\text { lant }\end{array}$ & $\begin{array}{c}\text { Pseudo } \\
\text { stem } \\
\text { length }(\mathbf{c m})\end{array}$ & $\begin{array}{l}\text { Polar bulb } \\
\text { diameter } \\
\text { (cm) }\end{array}$ & $\begin{array}{c}\text { Equatorial } \\
\text { bulb diameter } \\
\text { (cm) }\end{array}$ & $\begin{array}{l}\text { Bulb wt. } \\
\text { (g) }\end{array}$ & $\begin{array}{c}\text { No. of } \\
\text { cloves/bu } \\
\text { lb }\end{array}$ & $\begin{array}{l}\text { Av. wt. of } \\
50 \text { cloves } \\
\text { (g) }\end{array}$ & $\begin{array}{c}\text { Genotypic } \\
\text { correlation } \\
\text { with total yield } \\
\left(\mathbf{t ~ h a}^{-1}\right)\end{array}$ \\
\hline Plant height (cm) & -0.423 & 0.059 & 0.035 & 3.926 & 0.999 & 18.309 & 0.652 & 13.433 & $0.778^{*}$ \\
\hline No. of leaves/plant & 0.033 & -0.752 & 0.018 & 1.333 & 0.149 & 4.760 & 0.871 & 1.824 & $0.113^{* *}$ \\
\hline Pseudo stem length (cm) & 0.102 & 0.094 & -0.145 & 0.675 & 0.121 & 4.194 & 0.203 & 3.128 & $0.156^{* *}$ \\
\hline $\begin{array}{l}\text { Equatorial bulb diameter } \\
(\mathrm{cm})\end{array}$ & 0.315 & 0.084 & 0.013 & 4.312 & 1.343 & 20.256 & 0.409 & 15.621 & 0.845 \\
\hline Bulb wt.(g) & 0.326 & 0.151 & 0.026 & 4.743 & 1.144 & 23.780 & 0.197 & 18.526 & $0.957 * *$ \\
\hline No. of cloves/bulb & 0.141 & 0.333 & 0.015 & 1.332 & 0.281 & 2.395 & -1.956 & 0.056 & $0.056^{* *}$ \\
\hline
\end{tabular}

Residual effect $=0.473$ 